\title{
Znaczenie podatków ekologicznych dla dochodów budżetowych państw UE
}

The significance of environmental taxes in EU budgetary revenues

\section{Wprowadzenie}

Podstawową, klasyczną funkcją podatków jest funkcja fiskalna, polegająca na zapewnieniu państwu środków niezbędnych do jego funkcjonowania. Jednakże nie jest to funkcja jedyna. Wraz z rozwojem gospodarczym wprowadzanie podatków zaczęto łączyć z osiąganiem celów redystrybucyjnych, stymulacyjnych i gospodarczych (Podstawka, 2010, s. 471). W ostatnich latach natomiast coraz większą wagę przywiązuje się do kwestii ochrony środowiska i zmniejszania emisji zanieczyszczeń. Funkcjonujące w poszczególnych krajach systemy podatkowe zaczęły podlegać zmianom, które miały na celu uczynienie ich narzędziami do ochrony środowiska naturalnego. Proces ten szczególnie widoczny jest w UE, która za cel postawiła szersze stosowanie zasady „zanieczyszczający środowisko płaci” i przeniesienie ciężaru podatkowego z obciążeń pracy na podatki ekologiczne (PE, 2016, punkt 76). Mimo że akt ten wszedł w życie w 2016 r., to ogólne zalecenia co do podatków ekologicznych pojawiały się w dokumentach UE już od 2010 r. Niektóre zatem z państw UE już wcześniej zaczęły wdrażać te prośrodowiskowe zalecania. Istotne jest zatem zbadanie znaczenia tych obciążeń dla UE jako całości i poszczególnych krajów członkowskich.

Celem opracowania było określenie wielkości wpływów do budżetów państw UE z tytułu podatków środowiskowych oraz zmian, jakie zachodziły w ciągu ostatnich 13 lat (okres 2006-2018). Natomiast na gruncie teoretycznym podjęto próbę określenia podstaw teoretycznych funkcjonowania podatków ekologicz- 
nych w UE. Do porównań międzypaństwowych wybrano kraje o największych dochodach budżetowych $\mathrm{z}$ tego tytułu.

\section{Podstawy teoretyczne}

Legalna definicja podatków ekologicznych pochodzi z art. 2 Rozporządzenia Parlamentu Europejskiego i Rady UE nr 691/2011 (PE, 2011), gdzie nazwany jest on „podatkiem związanym ze środowiskiem”. Jest to dosłowne tłumaczenie pojęcia „environmental related tax”, jednakże w tym opracowaniu używany jest termin „podatek ekologiczny”, który częściej stosuje się w literaturze przedmiotu. Zgodnie z tym aktem jest to „podatek lub opłata, w którym podstawą opodatkowania jest jednostka fizyczna (lub odpowiednik jednostki fizycznej) substancji, której negatywny wpływ na środowisko naturalne został udowodniony i w systemie ESA 95 uznawany jest za podatek". Podatki te stanowią dochody szeroko rozumianego sektora finansów publicznych. Biorąc pod uwagę tę definicję, pojawiają się wątpliwości dotyczące charakteru tych obciążeń i podstaw teoretycznych, na jakich bazują (European Environment Agency, 2013, s. 13).

W teorii ekonomii za twórcę pojęcia podatku ekologicznego uznaje się A.C. Pigou. Koncepcja ta powstała na gruncie rozważań na temat efektów zewnętrznych związanych z różnego rodzaju działalnością człowieka (Pigou, 1932, s. 182-196). Pigou, podając kilka przykładów (emisja zanieczyszczeń z kominów fabrycznych, praca kobiet przekładająca się na niższą zdrowotność ich dzieci), zwrócił uwagę na fakt, że w wielu przypadkach skutki tych działań są znacznie szersze niż początkowo się wydaje. W efekcie nie wszystkie koszty (a czasem i korzyści) są uwzględniane w rachunku ekonomicznym. Powoduje to sytuacje, w których mechanizm rynkowy przestaje prowadzić do optymalnej alokacji dóbr. W przypadku negatywnych efektów zewnętrznych produkcja i konsumpcja danego dobra znajdzie się powyżej poziomu właściwego ze społecznego punktu widzenia. Pigou stwierdza, że rozwiązaniem tego problemu jest wprowadzenie przez państwo odpowiedniego systemu dopłat (dla korzystnych efektów zewnętrznych) i podatków (dla niekorzystnych efektów zewnętrznych). Podatek powinien być równy marginalnym kosztom społecznym na jednostkę produktu powodującego negatywne efekty zewnętrzne. Pozwoli to zniwelować rozbieżności pomiędzy indywidualnymi i społecznymi marginalnymi efektami zewnętrznymi. Idea ta, mimo prostoty, napotyka na wiele problemów praktycznych przy zastosowaniu, wynikających z jej konstrukcji. Pierwszy z nich wiąże się z kwestią określenia marginalnego kosztu społecznego jednostki produkcji, do czego wy- 
magana jest znajomości tzw. funkcji szkód środowiskowych (Gago, Labandeira \& López-Otero, 2014). Uzależniona jest ona od stanu środowiska naturalnego, możliwości absorbcji zanieczyszczeń, rodzaju emisji itd. Nawet przybliżone jej oszacowanie rodzi duże trudności, co może podważać legalność i celowość prowadzenia takiego podatku (Pezzey, 1988, s. 210). Co więcej, w założeniach podatek powinien być nakładany indywidualnie na każdy podmiot emitujący zanieczyszczenia, zatem stawki podatku dla każdego podatnika powinny być inne. Ponieważ jest to niezwykle trudne w praktyce, stosuje się tzw. rozwiązanie second-best. Nie bierze się tutaj pod uwagę rzeczywistej indywidualnej szkodliwości działań danego podmiotu, lecz ustala się jednolite stawki dla wszystkich (chociaż mogą się one różnić w zależności od branży). Stawka ta zależy najczęściej od względnej uciążliwości danej substancji (Fiedor, 2002, s. 88).

Z kwestią podatków ekologicznych wiąże się również porównanie ich skuteczności i kosztów w zestawieniu z innymi metodami ograniczania wpływu na środowisko. Ich bezsprzeczną zaletą jest osiąganie przez państwo dodatkowych dochodów, które mogą być zużytkowane na obniżenie innych podatków czy też na działania w celu ochrony środowiska. W tym kontekście pojawia się pojęcie podwójnej dywidendy (Goulder, 1995). Oznacza ono, że system podatkowy oparty na podatkach ekologicznych nie tylko prowadzi do poprawy stanu środowiska, lecz również ogranicza zakłócenia konkurencji w gospodarce, wprowadzane przez klasyczne podatki. Kolejnym pozytywnym aspektem są mniejsze możliwości unikania tego typu obciążeń, jak pokazują to przykłady Szwecji i Wielkiej Brytanii. W Szwecji unikanie płacenia podatków środowiskowych utrzymuje się na poziomie poniżej 1\%. W Wielkiej Brytanii stwierdzono, że wynosi ono 2\%, $\mathrm{w}$ porównaniu z $17 \% \mathrm{w}$ przypadku podatków dochodowych. Z drugiej strony w dużej części badań można zetknąć się z opinią, że w porównaniu z systemami opartymi na handlu uprawnieniami (ETS - Emission Trading System) czy też bezpośrednimi regulacjami (np. określone normy emisyjne) podatki ekologiczne to najdroższy sposób ograniczania zanieczyszczania środowiska. Pojawiają się tu również innego rodzaju wątpliwości - część ekologów za niemoralne uważa kupowanie prawa do zatruwania wspólnego środowiska (Romstad \& Folmer, 2000, s. 530).

W praktyce gospodarczej podatki ekologiczne nakładane są w wysokości wyższej niż spodziewany koszt społeczny. Oprócz powodów czysto fiskalnych (wzrost wpływów do budżetu), podawane są również argumenty teoretyczne. Podatki ekologiczne mają zmniejszać szkody dla środowiska, a im wyższa stawka podatku, tym bardziej służą jego ochronie, choć zarazem mocniej hamują one aktywność gospodarczą. Ponieważ jednak koszt społeczny zanieczyszczenia 
środowiska jest trudny do oszacowania, co pozwala przypuszczać, że przyszłe badania znacznie go powiększą, należy, zgodnie z zasadą ostrożności, dążyć do większej redukcji zanieczyszczeń. Rozważania te są szczególne istotne dla tzw. podatków węglowych, powiązanych z emisją gazów cieplarnianych (GC). Należy tu porównać kolejne raporty Międzynarodowego Zespołu ds. Zmian Klimatu (IPCC): pierwszy z 1990 r. (IPCC, 1990) i ostatni z wydanych, z 2013 r. (IPCC, 2015). Wyraźnie widać, iż poglądy na temat skutków ekonomicznych zmian klimatycznych ewoluowały wraz z postępem badań, pokazując znacznie poważniejszy charakter owych skutków niż wcześniej zakładano. Dobitnie uwidacznia to Raport Sterna (Stern, 2007), gdzie straty związane ze zmianami klimatycznymi oszacowano na 25\% globalnego PKB; dla porównania we wcześniejszych badaniach oszacowano je na 1-5\% PKB, przy wzroście temperatury o $4^{\circ} \mathrm{C}$ (Interagency Working Group on Social Cost of Carbon [IWGSCC], 2013, s. 9). Problem wydaje się otwarty, jednakże niektórzy badacze uważają, że ideą podatku Pigou jest dokładne odzwierciedlenie kosztu społecznego (w tym przypadku - kosztu emisji $\mathrm{CO}_{2}$ ), dlatego ustalanie stawek powyżej tej wielkości jest niezgodne z tymi założeniami (Weisbach, 2012, s. 23).

Podsumowując, występujące w tej chwili w UE rozwiązania dotyczące podatków ekologicznych nie bazują bezpośrednio na założeniach podatku Pigou. Co więcej, podatków ekologicznych w UE nie można wyróżnić ze względu na przeznaczenie środków pozyskiwanych z ich tytułu. Podatki, które są wykorzystywane w tym celu, stanowią jedynie pewną podgrupę podatków ekologicznych. W dalszej części opracowania pojęcie podatków ekologicznych będzie używane zgodnie z definicją Eurostatu.

\section{Materiały i metodyka badań}

W opracowaniu wykorzystano dane pochodzące z Eurostatu za lata 2006-2018. Do porównań pomiędzy państwami wybrano najważniejsze gospodarki UE, których wpływy z podatków ekologicznych stanowiły niemal 80\% wpływów w całej UE. Wyniki analiz przedstawiono w wielkościach realnych.

Podatki ekologiczne zostały w danych Eurostat wyodrębnione ze względu na określoną podstawę opodatkowania w jednej z czterech kategorii (Eurostat, 2013, s. 9-17):

- Energia - podatki obejmujące produkcje energii, surowce energetyczne, zarówno dla potrzeb transportowych, jak i stacjonarnego wykorzystania. Jeżeli chodzi o podatki związane z emisją $\mathrm{CO}_{2}$, to ze względu na kwestie 
statystyczne i brak możliwości ich oddzielenia od innych podatków energetycznych również należą one do tej kategorii (a nie do grupy Zanieczyszczenia). Tu również zakwalifikowane są dochody państwa ze sprzedaży praw do emisji $\mathrm{CO}_{2}$, w ramach aukcji EU Emissions Trading Scheme.

- Transport - kategoria obejmuje wszelkie podatki i opłaty związane z posiadaniem i użytkowaniem pojazdów mechanicznych: samochodów, motorów, samolotów, statków, samochodów elektrycznych z wyłączeniem paliw. Zawarte tu są również podatki importowe od środków transportu i obciążenia uzależnione od emisji $\mathrm{CO}_{2}$ przez dany pojazd. Opłaty związane z wjazdem do centrów miast również mogą być włączone do tej kategorii pod warunkiem, że są ujęte w rachunkach narodowych jako podatek.

- Zanieczyszczenia - do tej kategorii zakwalifikowano podatki wynikające ze zmierzonej lub oszacowanej ilości zanieczyszczeń wprowadzonych do powietrza, wody, gospodarowanie odpadami stałymi, a także wynikające $\mathrm{z}$ nadmiernego hałasu (wyjątek - związane z emisją $\mathrm{CO}_{2}$ ).

- Surowce - grupa to obejmuje obciążenia związane z wykorzystaniem zasobów naturalnych, takich jak woda, lasy, dzika flora i fauna. Jednakże wyłączone są podatki od gruntów oraz nieruchomości, chyba że są bezpośrednio związane ze środowiskiem, jak np. opłata za wylesienie.

- Oprócz listy obciążeń włączonych do kategorii podatków środowiskowych w wytycznych Eurostat znajdują się również podatki wyłączone:

- VAT, chociaż kwestia tego podatku jest dyskusyjna, gdyż nieliczne preferencyjne stawki VAT usług mają czasami na celu ochronę środowiska (Ogonowska, 2016).

- Podatki związane z nieruchomościami.

- Opłaty dotyczące praw do wydobycia kopalin (ropy, gazu), choć wykorzystanie zasobów pochodzących z innych źródeł (wydobycie minerałów, korzystanie z wód, leśnictwo) nie zostaje wyłączone.

- Podatki nakładane na poszczególne produkty - alkohol, tytoń, kawa (Eurostat, 2013, s. 9-17).

\section{Wyniki i dyskusja}

Okres badawczy 2006-2018 to czas burzliwych wydarzeń gospodarczych zachodzących w krajach UE. Zdarzenia te wiązały się głównie z kryzysem finansowym z 2008 r. oraz jego skutkami dla gospodarek państw UE. 
Rysunek 1. Wielkość wpływów z tytułu podatków ekologicznych w UE [mln euro] i ich udział w PKB [\%]

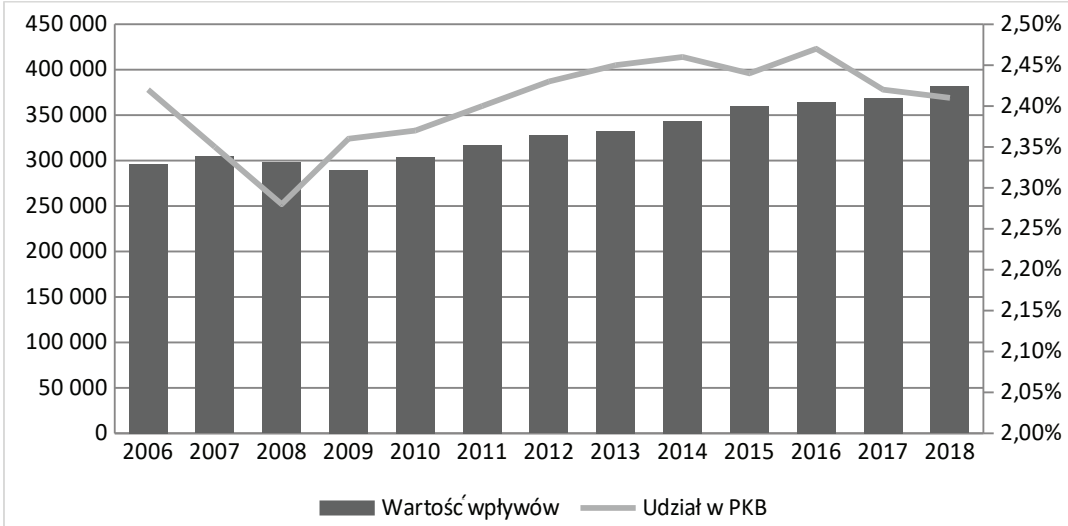

Źródło: Opracowanie własne na podstawie danych Eurostat (2013).

Na rysunku 1 przedstawiono wartość wpływów z tytułu podatków ekologicznych w całej UE. W badanym okresie wartość podatków ekologicznych wzrosła o 21\%. Jednakże w latach 2008 i 2009 można zaobserwować spadek tych dochodów. Przełamaniu uległ wówczas wieloletni trend wzrostowy, który dał się zaobserwować od 1995 r. (dane dla krajów UE-19, jak również dla krajów UE-28). Zdecydowana większość podatków ekologicznych, jak pokazano na rysunku 2 należy do kategorii energetycznych (łącznie z paliwami).

Rysunek 2. Struktura wpływów z podatków środowiskowych w wybranych krajach UE w 2018 [\%]

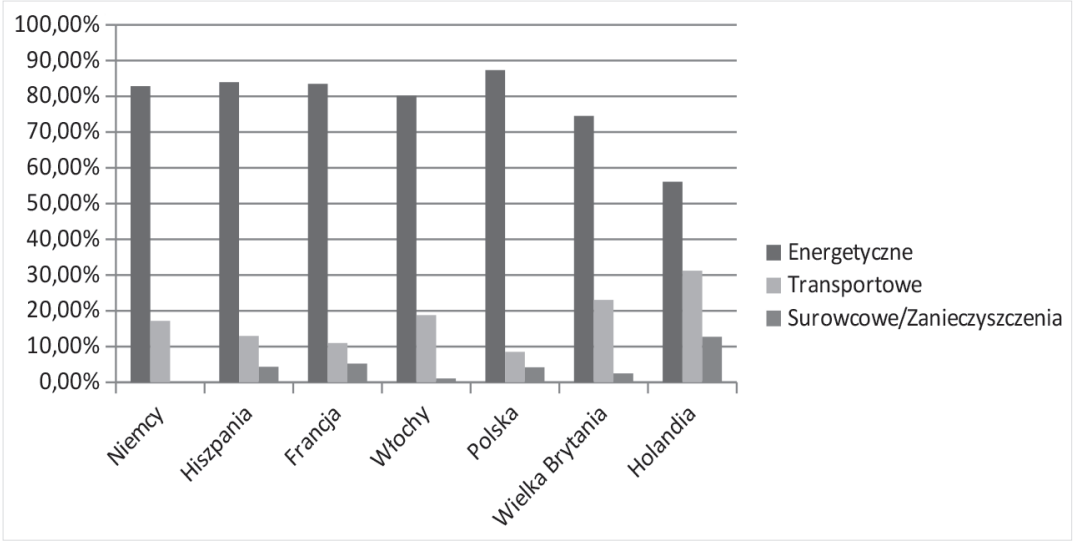

Źródło: Opracowanie własne na podstawie danych Eurostat (2013) 
Kryzys gospodarczy spowodował, iż znacząco obniżyło się nie tylko zużycie paliw w gospodarce UE, lecz doszło również do załamania cen produktów energetycznych. W Polsce pod koniec 2008 r. cena benzyny PB95 osiągnęła najniższy w okresie 2003-2018 poziom 3,1 zł za litr. Na podobną sytuację w całej Europie wskazują dane Eurostatu, według których ceny benzyny PB95 w całej UE spadły z poziomu 1,48 euro za litr na początku 2008 r. do 1 euro na jego koniec.

Warto również zwrócić uwagę, iż większość sektorów gospodarki UE znacząco poprawiła efektywność wykorzystania energii, co w połączeniu z ograniczonym wzrostem gospodarczym skutkowało obniżeniem popytu na surowce energetyczne (Gołasa, Wysokiński \& Bieńkowska-Gołasa, 2015). Jednakże zmiany dochodów z podatków środowiskowych nie przebiegały w ten sam sposób we wszystkich krajach UE.

Rysunek 3. Wartość wpływów z tytułu podatków ekologicznych w krajach UE [w mln euro]

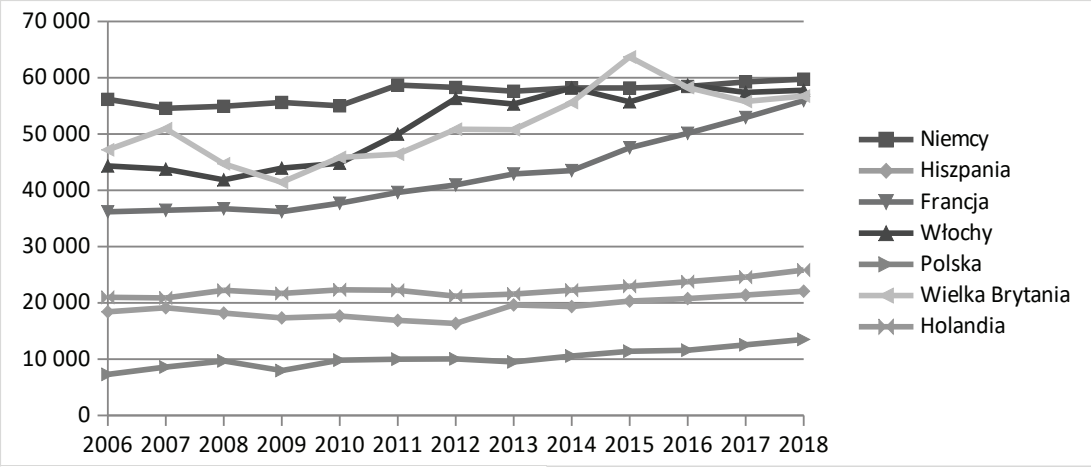

Źródło: Opracowanie własne na podstawie danych Eurostatu (2013).

Przedstawione na wykresie kraje odpowiadały w 2018 r. za 77\% wszystkich dochodów z podatków ekologicznych. Polska z wpływami na poziomie 13,5 mld euro znajdowała się siódmym miejscu i w badanym okresie zanotowała istotny wzrost tych dochodów o 72\% w porównaniu z 2006 r. Duże wahania wpływów z podatków ekologicznych zanotowano w Wielkiej Brytanii. Po znacznych spadkach w trakcie kryzysu gospodarczego w kolejnych latach wzrosły one do poziomu 56 mld euro, drugiego najwyższego w całej UE. Równie silne wzrosty zaobserwowano we Francji i we Włoszech. Te zmiany przełożyły się bezpośrednio na pozycje podatków ekologicznych wśród wszystkich obciążeń podatkowych, co przedstawiono na rysunku 4. Obciążenia te najmocniej odczuwalne są w Holandii, gdzie w 2018 r. odpowiadały za niemal 8,5\% wszystkich podatków. 
Rysunek 4. Udział podatków środowiskowych w całości dochodów budżetowych wybranych państw UE [\%]

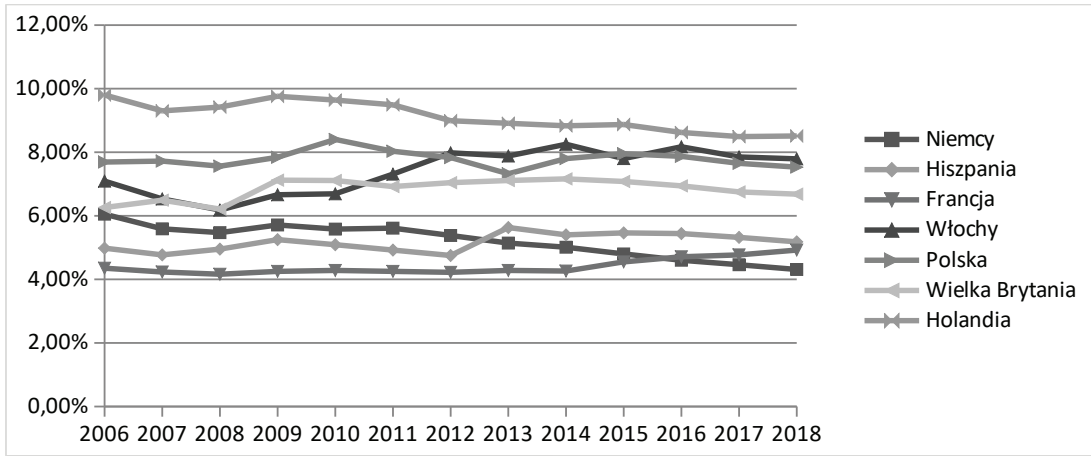

Źródło: Opracowanie własne na podstawie danych Eurostatu (2013).

Warto tu jednak podkreślić, że mimo apelu UE o odchodzenie od obciążenia pracy i konsumpcji na rzecz podatków ekologicznych, nie zaobserwowano tych zmian we wszystkich badanych krajach. Przykładem jest Polska, gdzie wskaźnik udziału podatków ekologicznych we wpływach podatkowych praktycznie pozostawał bez zmian i kształtował się na poziomie 7,5\%. Należy podkreślić, że jest to wartość powyżej średniej UE, wynoszącej w 2018 r. 6\%. Właściwie jedynie we Włoszech i w Wielkiej Brytanii doszło do zwiększenia tego udziału. Na przeciwnym krańcu znajduje się natomiast największa gospodarka UE - Niemcy, gdzie pomimo wzrostu gospodarczego udział podatków ekologicznych konsekwentnie ulegał zmniejszeniu.

\section{Podsumowanie}

Przedstawione wyniki badań prowadzą do następujących wniosków:

1. Określenie „podatki ekologiczne”, funkcjonujące w terminologii UE, jest raczej pojęciem technicznym, niezwiązanym ani z ideami podatku Pigou, ani z przeznaczeniem środków dzięki nim uzyskiwanych na poprawę stanu środowiska.

2. W UE zwiększa się presja na zastępowanie podatkami ekologicznymi podatków standardowych, co znajduje uzasadnienie w teorii podwójnej dywidendy.

3. W badanym okresie znaczenie podatków środowiskowych powoli rośnie, jednak proces ten nie jest ewidentny we wszystkich krajach członkowskich. 
4. Wysokość wpływów z podatków ekologicznych jest mocno uzależniona od koniunktury gospodarczej, gdyż opierają się one w głównej mierze na podatkach związanych ze zużyciem energii.

5. W największych gospodarkach UE wpływy z podatków ekologicznych stanowią od 4,3\% do 8,5\% wszystkich wpływów podatkowych, a średnio dla całej UE wynoszą 2,41\% PKB.

Jak pokazują przedstawione dane, proces zwiększania roli podatków ekologicznych w UE dopiero się zaczyna. Wśród największych gospodarek tylko niektóre z nich zaczęły odchodzić od opodatkowania pracy i konsumpcji na rzecz podatków ekologicznych. Wydaje się, że biorąc pod uwagę starania UE, mające na celu ochronę środowiska naturalnego (zwłaszcza przeciwdziałanie zmianom klimatycznym), coraz wyraźniejsze będą próby forsowania tych zmian. Potrzebne są zatem dalsze badania łączące funkcjonowanie podatków ekologicznych ze wzrostem gospodarczym, a także z korzystnym wpływem na środowisko, bez pomijania podstawowej, fiskalnej funkcji tych instrumentów finansowych.

\section{Bibliografia}

\section{Akty prawne}

Parlament Europejski. (2011, 6 lipca). Rozporzadzenie Parlamentu Europejskiego i Rady (UE) NR 691/2011 z dnia 6 lipca 2011 r. w sprawie europejskich rachunków ekonomicznych środowiska. Pobrano z: www.eur-lex.europa.eu (18.02.2020).

Parlament Europejski. (2016, 20 listopada). Rozporządzenie Parlamentu Europejskiego i Rady 1386/2013/UE z dnia 20 listopada $2016 r$. w sprawie ogólnego unijnego programu działań w zakresie środowiska do 2020 r. „Dobra jakość zycia z uwzględnieniem ograniczeń naszej planet". Pobrano z: www.eur-lex. europa.eu (15.01.2020).

\section{Literatura}

European Environment Agency. (2013). Environmental taxation and EU environmental policies. EEA Report No 17/2016, EEA, Copenhagen. Pobrano z: www.eea. europa.eu/publications/environmental-taxation-and-eu-environmental-policies (10.02.2020).

Eurostat. (2013). Environmental taxes, A statistical guide. Luksemburg: Publications Office of the European Union.

Fiedor, B. (red.). (2002). Podstawy ekonomii środowiska i zasobów naturalnych. Warszawa: C. H. Beck. 
Gago, A., Labandeira, X., \& López-Otero, X. A. (2014). Panorama on Energy Taxes and Green Tax Reforms. Review of Public Economics, 208(1), 145-190. https://doi. org/10.7866/HPE-RPE.14.1.5

Gołasa, P., Wysokiński, M., \& Bieńkowska-Gołasa, W. (2015, 8-11 czerwca). Energy consumption in the iron \& steel industry in EU member states in light of the theory of environmental economics. METAL 2015: 24th International Conference on Metallurgy and Materials: Brno, Czech Republic, EU.

Goulder, L. H. (1995). Environmental taxation and the „double dividend”: a Reader's guid. International Tax and Public Finance, Working Paper, 4896, 157-183. https://doi.org/10.1007/BF00877495

Interagency Working Group on Social Cost of Carbon. (2013). Technical Support Document: Technical Update of the Social Cost of Carbon for Regulatory Impact Analysis under Executive Order 12866. Pobrano z: www.19january2017snapshot. epa.gov (8.02.2020).

IPCC. (1990). Climate Change, The IPCC Scientific Assessment. Cambridge: Cambridge University Press. https://doi.org/10.1002/joc.3370110409

IPCC. (2015). Zmiana klimatu 2013. Fizyczne podstawy naukowe. Podsumowanie dla decydentów. Przyczynek I Grupy Roboczej do piątego raportu oceny zmian klimatu międzyrządowego Zespołu ds. zmiany klimatu. Pobrano z: www.ipcc.ch (12.12.2019).

Ogonowska, A. (2016). Ekologiczne aspekty w polskim systemie podatków. W: W. Bożek (red.), System podatkowy w Polsce: jego rola i znaczenie w procesach gospodarowania (s. 263-278). Szczecin: Wydział Prawa i Administracji Uniwersytetu Szczecińskiego.

Pezzey, J. (1988). Market mechanisms of pollution control: 'Polluter Pays', economic and practical aspects. W: R. K. Turner, Sustainable Environment Managment: Principles and Practises (s. 190-242). Londyn: Belhaven Press.

Pigou, A. C. (1932). Economics of Welfere (wyd. 4). Londyn: Macmillan and Co.

Podstawka, M. (red.). (2010). Finanse, instytucje, instrumenty, podmioty, rynki regulacje. Warszawa: PWN.

Romstad, E., \& Folmer, H. (2000). Green Taxation. W: H. Folmer, \& L. H. Gabel, (red.), Priciples of Enviromenmental and Resources Economics. A Guide for Students and Decizion-Makers (wyd. 2, s. 529-563). Northampton: Edward Elgar Publishing, INC.

Stern, N. (2007). Stern Review: The Economics of Climate Change. Cambridge: Cambridge University Press. https://doi.org/10.1017/CBO9780511817434 


\section{Streszczenie}

Celem artykułu było określenie wielkości wpływów do budżetów państw UE z tytułu podatków środowiskowych oraz zmian, jakie zachodziły w ciągu ostatnich 13 lat (okres 2006-2018). Na gruncie teoretycznym natomiast podjęto próbę określenia podstaw teoretycznych funkcjonowania podatków ekologicznych w UE. Stwierdzono, że określenie „podatki ekologiczne”, występujące w terminologii UE, jest pojęciem technicznym, niezwiązanym z teoretycznymi założeniami podatku Pigou. Natomiast zwiększająca się w UE presja na zastępowanie podatkami ekologicznymi podatków standardowych uzasadniana jest zjawiskiem podwójnej dywidendy.

W badanym okresie na podstawie danych Eurostatu stwierdzono niewielki wzrost znaczenia podatków środowiskowych, znacznie różniący się jednak w poszczególnych krajach UE. Zauważono, iż wielkość wpływów z tego tytułu powiązana jest ze zużyciem energii. W największych gospodarkach UE wpływy z podatków ekologicznych stanowią od 4,3\% do $8,5 \%$ wszystkich wpływów podatkowych, co dla całej UE stanowi średnio 2,41\% PKB.

SŁOWA KLUCZOWE: podatek Pigou, efekty zewnętrzne, dochody podatkowe

\section{Summary}

The objective of the present article was to determine the amount of income from environmental taxes to EU national budgets and the changes that took place over the last 10 years (from 2006 to 2018). In terms of theoretical knowledge, however, an attempt was made to define the theoretical foundations for the functioning of environmental taxes in the EU. It was pointed out that the term 'environmental taxes' in the EU terminology is a technical term, not linked to the theoretical assumptions of a Pigovian tax. However, the increasing pressure in the EU to replace environmental taxes with standard taxes is justified by the phenomenon of double dividend.

On the basis of Eurostat data, during the period under review a slight increase in the importance of environmental taxes was observed, however, it varies considerably across the EU. It was observed that the amount of payments is strictly connected to the energy consumption. In the largest EU economies, environmental taxes revenues account for between $4.3 \%$ and $8.5 \%$ of all tax revenues, which, on average, for the EU as a whole accounts for $2.41 \%$ of GDP.

Keywords: environmental taxes, a Pigovian tax, externalities, tax revenues

\section{Nota o autorze}

Piotr Gołasa - dr hab.; Szkoła Główna Gospodarstwa Wiejskiego w Warszawie, Wydział Nauk Ekonomicznych, Katedra Finansów; główne dziedziny działalności naukowej: rolnictwo a środowisko, emisja gazów cieplarnianych, dochody w rolnictwie, prawne aspekty działalności rolniczej; e-mail: piotr_golasa@sggw.pl; ORCID: 0000-0002-8848-1122. 